\title{
HISTORIA CULTURAL: UNA AVENTURA DEL ESPÍRITU
}

\author{
José Enrique Ruiz-Domènec \\ Universitat Autònoma de Barcelona \\ JoseEnrique.Ruiz.Domenec@uab.cat
}

Visto en retrospectiva, el informe presentado por Peter Burke con el título What is Cultural History?, y publicado en 2004 por la editorial Polity Press de Londres, se nos presenta como uno de los primeros intentos de fijar el lugar de la historia cultural en el siglo Xxi (Burke 2004). Desde entonces ésta goza de buena salud en el mundo académico y en la industria editorial, como prueban los libros de dos renombrados medievalistas: el de Patrick J. Geary sobre los orígenes del mito de las amazonas (Geary 2006) y su proyección en el sistema de creencias, y el de Gâbor Klaniczay sobre el carácter sobrenatural del poder de los reyes (Klaniczay 1990).

Historia cultural, en suma. Su método es narrativo. Su tema es el mundo vital de un episodio o un momento del pasado que está medio olvidado. Y su misión, darlos a conocer, en la convicción de que sólo hay auténtica información si hay comunicación.

El despertar de la historia cultural se relaciona, en primer lugar, con su emancipación de algunas disciplinas afines como la historia social o la historia de las ideas y, en segundo lugar, con la guerra de las culturas provocada por el llamado "giro lingüístico" en los mismos años en que se estaba desmantelando el marxismo político académico, junto al muro de Berlín, y que entre otras consecuencias condujo a replantear el oficio de historiador en la cuarta generación de los Annales y el sentido del cánon de los estudios sobre la Edad Media de la mano de los mentores del llamado "New Medievalism", con Stephen S. Nichols a la cabeza (Nichols 199I). Hoy la historia cultural está en un buen momento, en gran parte porque ha sabido definir con rigor su campo de investigación: la cultura es la expresión de una sociedad.

Para aclarar la distancia que existe entre la historia cultural que se hacía entre I860 y 1920 y la que se hace hoy voy comparar el clásico (y de efectos duraderos) Die Kultur der Renaissance in Italien de Jacob Burckhardt (I860), una investigación sobre la formación de la individualidad y la imagen del poder como obra de arte en el mundo italiano de los siglos XV y Xvi, con el libro de Stephen Greenblatt The Swerve. How the World Became Modern, publicado por la editorial Norton de 
Nueva York en 20II, una investigación sobre el efecto "cultural" provocado por el hallazgo del De Rerum Natura de Lucrecio en Italia a comienzos del siglo xv (Greeenblatt 20iI). Si en el primer caso el estudio de la cultura se convertía en el marco perfecto para estudiar el arte, la política o las costumbres de una sociedad, en el segundo caso las pesquisas sobre la función social de un manuscrito permiten desentrañar el giro que hizo posible el mundo moderno.

Me parece enormemente significativo que Stephen Greenblatt, un reputado profesor de humanidades en Harvard además de una celebridad mundial, que en otro tiempo encabezó el New Historicism, haya dedicado su talento y capacidad de análisis al servicio de un argumento de la historia cultural. Su propuesta nos abre un campo de experiencia extraordinario. Piénsese en un estudio de la pose en los retratos femeninos del Renacimiento: en su momento fueron entendidos con toda claridad como exaltaciones tanto de la relevancia de las familias adineradas de las ciudades como de la doctrina de la belleza en tanto que honor social; en la actualidad, las creencias y supuestos que conforman la mirada de los pintores que realizan tales retratos no tiene sentido para nadie, precisamente porque todos esos pintores fueron hombres de su tiempo; en muchos sentidos, fueron los biógrafos de la condición femenina. Sin embargo, un análisis basado en los principios de la historia cultural permite entender la lógica social que hizo posible los retratos, y su razón de ser estética y política.

La historia cultural en el siglo xxI ha abierto el espacio a una transversalidad no líquida sino rocosa, metodológicamente sólida, capaz de analizar las huellas del pasado en las arenas del tiempo. El momento clave de esta forma de estudiar el pasado, que tan ardientemente se ha buscado, ha llegado por fin con los estudios que entienden la cultura como un acontecimiento. Y si sabemos utilizarlo, la asignatura de Historia que actualmente se dicta en los institutos y colegios será bien distinta de lo que es ahora. Si así fuera, el rechazo a esta disciplina no estaría tan extendido, sino que se vería como un estimulante modo de pensar el presente; suya sería la responsabilidad de encauzar a los ciudadanos del futuro por el camino de la tolerancia y el respeto a los demás.

Sí, en efecto, la historia cultural es una aventura del espíritu completamente necesaria para el siglo XXI.

\section{REFERENCIAS}

Burke, P., ¿Qué es la historia cultural?, Barcelona, 2004. Greenblatt, S., The Swerve. How the World Became Modern, Nueva York y Londres, 20II. 
Geary, P. J., Women at the Beginning. Origin Myths from the Amazons to the Virgin Mary, Princeton y Oxford, 2006.

Klaniczay, G., The Uses of Supernatural Power, Londres, 1990.

Nichols, S. G., "The New Medievalism: Tradition and Discontinuity in Medieval Culture", en The New Medievalism, ed. M. S. Brownlee, K. Brownlee y S. G. Nichols, Baltimore y Londres, I99I, pp. I-28. 